\title{
SPIRITS, ICONOCLASTS AND THE BORDERS OF THE MARKET IN URBAN VIETNAM
}

\section{PHILLIP TAYLOR}

$\mathrm{T}$ his study takes as its object a goddess called the Lady of the Realm, whose shrine is in a rural area in the southern part of Vietnam. This goddess provides a valuable window onto changes underway in reform-era Vietnam for in recent years she has become the focus of a major pilgrimage and the controversial object of much commentary and debate. One of the more remarkable aspects of this figure is that although located in a rural region, she attracts many pilgrims from Ho Chi Minh City, the country's largest city and one of its most dynamic economic centres. Many of the fiercest critics of the practice of venerating this goddess also reside in Ho Chi Minh City. This study explores the interpretive dimensions of urban people's approaches to this goddess. It shows the Lady of the Realm to be pivotal to the way residents of Ho Chi Minh City envisage their city's transition to the market economy and their encounter with global forces. She is a crucial medium through which urban people construe economic agency and delineate their place in society.

My approach to this female spirit is not as much to investigate in depth the religious practice that condenses around this figure, ${ }^{1}$ as to explore the identitymarking function of such a figure, as an icon who represents and makes phenomenologically cogent such aspects of urban experience as the imagined borders of the urban world, historical sub- jectivity and distinctions of social status. The goddess at the heart of this story is used by some urban residents to map out differences between the countryside and the city. She is a vernacular construct through which urbanites position themselves within a process that is often abstractly referred to as economic 'integration' or 'globalization'. This goddess also features in the telling of urban history as a key figure through which recent societal transformations are imagined and played out. She is a means by which people employ themselves as actors in a history of economic liberalisation and contest the position of others in such terms. As a marker of social status she is also employed to assert competing visions of urban authenticity. She is an instrument through which status differences within urban society are practically secured. In short, this goddess is a construct around which contemporary Vietnamese urban identities are articulated and defended. Through the views expressed about this goddess we can see that a purportedly universal construct such as the 'market economy' is symbolically constituted and locally situated in place, time, and status.

\section{LOCALISING SPIRITUALITY}

When I met him, Tien served as the marketing manager of a multinational cosmetics company based in Ho Chi Minh 
City. ${ }^{2}$ He was responsible for establishing prices, setting up a distribution network and promoting the brand-names of a line of foreign made products in the rural areas surrounding the city. Tien told me that I would find little material of relevance to my proposed project of investigating the pilgrimage to the Lady of the Realm by staying in the city:

Only people down in the countryside believe in such mysterious kinds of things. Up here in the city, people's cultural level (trinh do van hoa) is higher; our way of life is modern (van minh), and consequently very few believe in that kind of thing.

Tien's way of reckoning the urban/ rural distinction is widely accepted in Vietnam: the city is regarded as 'above' (tren) the countryside, in its cultural and technological 'level'. From the city one 'goes down to the countryside' (xuong duoi que), whose residents, by virtue of their limited attendance of government schools, are said to have a 'low cultural level' (trinh do van hoa thap) and whose thatched palm leaf houses are frequently described as 'poor' (ngheo). From the perspective of many people who live in the countryside one goes 'up to the city' (len thanh $p h o$ ) a place identified with a builtup environment, elite cultural attainments and prosperity, attributes implied in the term van minh (civilized/modern). One also travels from the 'deep' or 'back' (sau) regions of the countryside 'out' ( $r a$ ngoai) to the 'market' (cho), the vernacular term for urbanized areas in the Mekong delta. Those situated in these urban areas themselves look 'out' (ngoai) to foreign countries; the term 'foreign' attaches principally to those countries that are seen as 'higher' (cao hon) in terms of wealth and socio-economic development.
From this perspective, the largest shrine to the Lady of the Realm, in the Mekong delta more than 250 kilometres from Ho Chi Minh City, is indeed 'down deep' in the Vietnamese countryside. Urban-based intellectuals such as Tien regard the area around her shrine as 'remote' (vung sau, vung xa), separated from the rest of the country by wide river branches that have proven difficult to bridge and that overflow their banks annually, making travel by road impossible for months. The Mekong delta is often seen as a place unto itself, whose geographical inaccessibility has allowed older religions such as Islam and Theravada Buddhism to persist, while nurturing the emergence of new indigenous faiths like the Hoa Hao and Cao Dai religions. The western stretches of the delta, where the shrine to the goddess is found, is pervasively associated in Vietnamese historical writings with grassroots prophets, peasant rebellions and unorthodox religious movements, virtue of its distance from the Vietnamese cultural centre. ${ }^{3}$ The delta's rich religious culture is sometimes linked to its unusually abundant environment. Influential historian of the intellectual history of Vietnam and former head of the southern Vietnamese chapter of the Indochinese Communist Party, Tran Van Giau referred to the delta as a living theme park for superstitions: 'The Mekong delta is an extremely fertile piece of earth, one which has given birth to many strange religions, and where superstitions are rife' ${ }^{4}$ This mocking tone calls attention to the failure of Vietnam's Marxist historians to reconcile the western delta's intense religiosity with its prodigious agricultural productivity and its residents' weak historical commitment to the communist path, despite their high degree of proletarianisation. ${ }^{5}$ A combina- 
tion of ethnic chauvinism and modernist bias prevents many urban intellectuals from recognising the wealth of local cultural forms found in the delta, including its concentration of Khmer monastic schools, Islamic Madrasas and ethnic Chinese schools, its high incidence of multilingualism and its diverse traditions of religious self cultivation and community medicine. ${ }^{6}$ According to many urbanites the thriving cult of the Lady of the Realm, centred in what they regard as a culturally peripheral region, merely confirms their ideas about the Mekong delta as a rural backwater and a site of persistent localism.

An alternative, more positive conception of the goddess is found among Vietnam's folklorists. These consider her cult 'the spiritual product of an agricultural people'. ${ }^{7}$ Some folklorists associate her with fertility beliefs surrounding wet rice farming, the dominant form of agricultural production in the Mekong delta. ${ }^{8}$ Her annual festival, which occurs at the end of the dry season, according to the lunar calendar, encodes age-old and cyclical environmental rhythms that organize the lives of people who are engaged in farming occupations. ${ }^{9}$ Shrines of this kind are also seen to demarcate space. Located on the margins of rural settlements and venerated chiefly by the residents of local communities, such religious institutions are thought to mark out the restrictive horizons of the rural world. ${ }^{10}$ According to these observers such festivals also serve to reflect, revitalize and reinforce bonds between members of rural society, underline their shared collective existence and integrate them into a cohesive community. ${ }^{11}$ As a figure who is integral to the temporal, spatial and social existence of the inhabitants of the Mekong delta, her cult is hence seen as an instance of the ritual 'production of locality,' according to which logic, 'space and time are themselves socialised and localised through complex practices of performance and representation and action'. ${ }^{12}$

Such depictions of the cult to the Lady of the Realm as largely a local or rural affair fail to come to terms with the enormous geographical extension of her following. While the shrine to the goddess is indeed found in a small rural village, the majority of those who visit her shrine do not come from this circumscribed territorial unit. The festival attracts people from all over the southern region and pilgrims travel in buses, motorbikes and boats to visit her, many of them bringing along provisions and sleeping in nearby pagodas and guesthouses. The greatest numbers of visitors come from the network of markets and urban centres within the southern region. In an estimate ventured to me by local shopkeepers, forty percent of the visitors to their area come from the one city of Ho Chi Minh City alone. In addition she attracts many visitors from overseas, particularly former Vietnamese citizens. These components of her following, which are scarcely mentioned in the commentaries produced by local folklorists, caution us against seeing this goddess as the spiritual product of an isolated, ecologically autarchic or remote rural community. Her attraction to city dwellers in particular suggests her relevance to the lives of urban residents and the existence of significant relationships between such a site and the urban locales from which the pilgrims are drawn.

The majority of these pilgrims do not attend the annual sacrifice to the goddess and are not directly exposed to the ideas 
that folklorists and the shrine's management committee promote of the goddess as a local protector deity. Instead ideas about her efficacy that members of this translocal following entertain are largely dependent on tales that circulate in marketplaces and urban neighbourhoods or are exchanged among followers in the precincts of her shrine. Her repute as a powerful being and conceptions of her magical capacity are forged in contexts far away from her shrine, in discussion between family, neighbours and colleagues, as too are ideas about the appropriate methods of accessing her power. Practices associated with her pilgrimage, such as divination and mediumship, consumerist influences in her festival and the commercialisation of the site around her shrine are taken by some folklorists to mean that this religious practice is losing coherence. These processes are mourned by those who find longevity and local colour in such rites, and who construct the goddess as an ancient, localistic and autarchic practice. ${ }^{13}$ Yet rather than see such practice as disintegrative, an alternative picture of this goddess would situate her at the centre of a broad and diffused spatial following whose members identify and transact with her in ways that reflect the diverse contexts from when they are drawn.

\section{DELINEATING MODERN AGENCY}

Like Tien, many educated and professional urbanites with whom I have spoken in Ho Chi Minh City consider the worship of the Lady of the Realm to index a past that their city has left behind. Tuyen, a teacher trained in the city, explained to me that the worship of the Lady of the Realm was a survival from an earlier pioneering era's misapprehension of the forces of nature:
The first Vietnamese settlers in the Mekong delta were only half-civilized. They lived in a dangerous and uncontrollable environment, subject to storms, dangerous animals and unfamiliar seasonal rhythms. Because they were not well educated they explained natural calamities in terms of the actions of spirits and other supernatural forces.

According to this view, spirit worship is a survival from primitive times when people failed to clearly understand the natural forces that influenced their lives, instead explaining them in ways that afforded them a sense of familiarity and control. To Huyen the people who live in the Mekong delta still live close to nature, subject in recent years to floods, storms and pest invasions and lacking adequate technological resources to counter its worst aspects. The worship of whales, rocks, trees and mountain dwelling goddesses, practices that are prevalent in this area, are representative of its residents' continued resort to the spirit world to make up for their weak mastery of the natural environment.

This evolutionist critique of spirit worship is often associated with the Marxist orientation of the present government but underlying this is the influence of enlightenment thinking shared by Vietnam's non-Communist intellectuals past and present. Early in the twentieth century Vietnamese intellectuals embracing Eurocentric concepts of science, denigrated spirit worship as functionally unsustainable, considering such practice as a form of false knowledge based on misunderstanding or deceit. In their search for bases upon which to build a viable national community Vietnam's urban intellectuals thought reliance on the spirit world undermined 
people's self belief and the efficacy of this-worldly answers to social injustice. ${ }^{14}$ Such religious practice was regarded as 'feudal' (phong kien) implicated in the sanctioning of power inequalities and the reproduction of exploitative social relations. In the building of the Democratic Republic of Vietnam practices negatively labeled 'superstition' (me tin di doan) included those customs and rites considered wasteful of national resources or undermining attachment to socialist programs of collective advancement ${ }^{15}$ Goddess worship was considered a suspect Taoist import from China and in the context of war with America, one prominent theme was the use of such practices by the enemy to subvert national unity. ${ }^{16}$ At the same time the government has not been averse to promoting the veneration of ancestral spirits, who exemplified its view of positive national traditions of heroism, revolution and resistance. ${ }^{17}$ In recent years this resistance pantheon has been greatly expanded to incorporate goddesses, whose worship is now considered iconic of national identity, an expansion aided by the reconstruction of goddess cults as ancient, local and grassroots practice. ${ }^{18}$

Today the attitudes towards goddess worship espoused by many educated professionals in Ho Chi Minh City diverge from the government's line in seeing such practice at odds with their vision of Vietnam as a realised modern nation. Tien, who considered goddess worship an embarrassing sign of the nation's lingering backwardness, is one of many intellectuals I spoke with who variously repudiated the logic of, professed disinterest in, or dismissed the relevance of such practice. One hears the confident view expressed by self-identified moderns that the Lady of the Realm is a phenomenon destined to die out as Viet- nam advances further into modernity. A great number of Ho Chi Minh City's educated professionals, technically trained workers and corporate managers, consider themselves at the avant-garde of liberalization and the localization of prestigious new forms of foreign culture and as agents spearheading the nation's global integration. In the idealistic and somewhat grandiose conceptions of this encounter often espoused by such people there is no place for the symbolic and ideological supports of ways of life that are considered 'old', subsistence-based, autarchic or communalist.

However, one also sometimes hears from urban intellectuals a more moderate view of spirit worship as a mechanism for coping with the dramatic changes unleashed by economic reform. According to some local observers, as a contemporary phenomenon, worship of goddesses such as the Lady of the Realm is a spiritual response to crisis, whose recent growth reflects the extremely high incidence of psychological, familial and economic crises that have attended the complex and unstable transition to a market economy. Goddess worship is a way of coping with the dislocation and confusion of rapid change. ${ }^{19}$

In a similar vein, although Tuyen consigned spirit worship to primitive circumstances, she also admitted that it had a psychologically useful role to play for those who were struggling to make ends meet:

Many of those who go to propitiate her are poor and endure precarious economic circumstances. One of the most common practices is to borrow a small amount of money from her. This has no real economic benefit, however, it encourages people to think that they have procured the patronage of a powerful being. Belief 
in her responsiveness to their prayers increases people's own self-confidence. It helps them endure uncertainty and economic misfortune.

Such psychologically functionalist views, however sympathetic, wedge open a space for tacit disqualification of the primary reality of such religious practice. To Tien, religion is a compensatory outlet for those who cannot cope with harsh realities. He said that the Asian financial crisis that hit Vietnam in the late 1990s had shattered many people's lives and had caused them to doubt that a marketbased economy could provide a better alternative to the old centralized socialist system. Tien compared the contemporary vogue in spirit worship with the events of the 1930s and 1940s when there had been a succession of political failures on the part of nationalists and communists, as a consequence of which, he claimed, many frustrated anti-colonial protestors had turned to such apocalyptic religions as the Cao Dai and Hoa Hao for solace. According to him people's contemporary resort to religion was similarly a consolation for failure in the 'real' world of the market economy.

The problem with such compensatory theories of religious movements, as Holsten has noted, is that they inevitably 'relegate manifestations of the popular imagination to the margins of the real business of modern states and societies'.$^{20}$ However, to regard popular veneration of a spirit such as the Lady of the Realm as a somehow transitory, escapist or compensatory phenomenon is to miss its most vital dimension, as a set of practices that is nested within Vietnam's contemporary engagement with market forces. Indeed, to counter suppositions such as Tien's, while the goddess was indeed propitiated during the economically depressed years of the 'Asian Crisis,' she was just as popular during the boom years of the early 1990s, when Vietnamese people were generally optimistic about improving their standard of living and many attributed their advances to her. Indeed by tracing the history of her following we can see continuities in this practice that cast the history of economic liberalisation in a new light.

\section{HISTORICISING THE MARKET}

In mid-2003 I asked a class of students in Ho Chi Minh City's College of Social Sciences why they thought people in their city had such a strong attraction to a goddess in a distant rural area. One of them suggested that the pilgrimage was tied up in the city's history of migration. Since the economic reforms began, Ho Chi Minh City has been the nation's prime recipient of migrants and a good proportion of these have come from the Mekong delta. According to this person, belief in this goddess had come to the city following a flow of migrants from rural areas and the pilgrimage to this goddess is a way that such migrants retain touch with their roots.

Many of those from the city who undertake pilgrimages to the Lady of the Realm do indeed come from the Mekong delta. There is significant evidence that the identity and powers they attribute to her match constructions of the goddess as a localistic protector deity advanced by Vietnam's folklorists. ${ }^{21}$ Many migrant workers make offerings to the goddess for good health, considering their well-being the greatest blessing she can confer upon them. The goddess is also attributed with conferring bodily security. By physically accessing the image of the goddess, by stroking or tapping her, one can transfer her powers to protect one's own body. People sometimes seek to obtain robes 
or pieces of cloth that have been in contact with the goddess, with which they wipe themselves over. People also seek the run-off water from her ritual bath and use it to wash their faces and bodies. It provides a protective film, defending the integrity of the body against disease, injury and the operation of curses. These approaches to the goddess confirm the view of Hanoi-based folklorist Ngo Duc Thinh who has argued that requests for health, today as in the past, comprise a key attribute of Vietnam's mother goddess cult. $^{22}$

Yet there is also evidence that such practices represent a response to the circumstances migrants face in their new urban home. Male motorcycle taxi drivers in the downtown area of the city, most of them migrants, told me that one can obtain from Her Ladyship's shrine a set of blessed offerings or loc sufficient to cover all one's basic needs. A package of salt and rice will ensure that one has enough to eat throughout the year. Gold and silver painted paper bring one money: 'enough to spend' ( $d u x a i)$ for a year. A leaf of gold represents investment capital, and pair of candles allow the light $(d u o c)$ of Her Ladyship to fill one's house. This set of gifts ensures success in making a living (lam an). Given the difficulties of their job, the hopes they invest in the goddess for basic subsistence, although modest, are relatively ambitious. Their view reflects the perspective of those who, at best, live from day to day, for whom fares are scarce, and whose motorbikes are often repossessed by creditors lending money at usurious rates. To be sick might mean defaulting on a loan repayment and courting ruinous loss of capital. If a family member is sick the cost of treatment might require they sell their motorbike, plunging them into desperate poverty.
One of the qualities that is today most frequently associated with the goddess is her assistance in making people's fortunes grow. Like the goddess Ba Chua Kho, the Lady of the Storehouse, whose shrine is just north of Hanoi, ${ }^{23}$ the Chau Doc goddess is widely seen by people in Ho Chi Minh City as a spirit of financial increase. In a similar folk religious tradition to that which Harrell ${ }^{24}$ and Gates ${ }^{25}$ have studied in China, people 'borrow' bank notes from her, which are imbued with the power to magically augment one's own financial reserves. Nga, a seamstress and dedicated Chau Doc pilgrim told me that the main reason people went to Her Ladyship's shrine in Chau Doc was to borrow money: 'The money is wrapped up in red paper envelopes (bao) in trays on the altar. There also is replica money, stamped gold sheets, gold and silver foil and colored paper. There is no shortage of money. You bring it home and place it on the altar to the god of wealth in your house. It will make your money grow, no fear.' The practice of making offerings to the goddess for assistance with business is widespread among entrepreneurs who associate her with commercial success. One of the requests most commonly made of the goddess -'lucky purchases and quick sales' (mua may ban dac) - is the small businessperson's mantra.

These appeals to the goddess bear witness to the central role the market has come to play in the lives of most people in this region of Vietnam. The goddess is closely associated with the financial practices that have characterised commerce in recent times. Not only do people borrow from her, but those who lend out money for interest or manage credit associations (huis), often seek her assistance in securing outstanding repayments. Such informal credit practices have become a preferred means of obtaining credit in 
a country where institutional banking is not well-established. Much economic activity in this period has been dependent on informal channels of credit and its use is regarded as normal business practice. People who sell in the market routinely extend purchasing credit to customers while simultaneously participating in huis and borrowing from private money lenders. Many people also borrow money for education, health needs, land acquisition and house building. Credit is widely used by young people to finance leisure pursuits and status-oriented consumer purchases. Yet transacting with informal credit brokers in an economically unstable and unpredictable environment is a risky business and many people have experienced the social relations of credit as demanding, threatening and pitiless. Migrant laborers and hopeful petty entrepreneurs who have flocked into the city from the countryside, for instance, have borrowed money for rent, business capital, and assistance for family needs back home. In the precarious circumstances of establishing themselves in the city, they have experienced with particular intensity the volatile and contradictory emotions associated with credit: a sense of freedom, dependence and vulnerability. For such people, this goddess, with her punitive rages, her reputed capacity to trouble people in their sleep, to choke off sales and inflict violent death is the very face of the finance markets.

The goddess can therefore be seen as an idiom through which a significant proportion of the urban population engage with their contemporary commercialised existence. The goddess symbolically models the experience of market relations and at the same time serves as a critique of its practices. She is a way of making intelligible the new and often disorienting experience of migration to the city according to a conceptual scheme that is familiar to most migrants. This observation recalls Jackson's discussion of the 'postmodernisation of Thai Buddhism'. Jackson argues that the rural flavour and traditionalist symbolic aspects of prosperity cults in urban Thailand can be to some extent accounted for as the projection of rural people's folk conceptual registers onto their new experiences as migrants of urban life and commerce. ${ }^{26}$ The advantage of this perspective is that it brings migrant experiences into the heart of the narrative of urban economic history. My only problem with this approach is that it renders such believers as agents after the fact, who offer vernacular interpretations that make sense of, and, through ritual means, attempt to control a system that is otherwise taken as a given.

An alternative view is to see the goddess herself as an agent of historical change. One of the factors feeding into the Lady of the Realm's notoriety as a patron of business in the early 1990s, and the huge boost in her following at that time, is the perception of her efficacious patronage of trade in pre-reform times. In the decade following the northern-based communist government's victory in the South in 1975, the socialist state made attempts to centralize its control over the southern economy by eradicating private distribution networks, which for centuries had been dominated by urban based ethnic Chinese, whose allegiance to the new socialist regime was considered suspect. The exodus of the ethnic Chinese in the aftermath of these policies is well known, as are the subsequent years of economic crisis and the state's dramatic rehabilitation of private markets as a valid component of a socialist economy in the mid-1980s. ${ }^{27}$ However, missing from most narratives of these 
turbulent times is the role played by the female-dominated informal sector in the urban south, in precipitating or coercing the liberal reforms. My interviews with people who continued trading during this period suggest that after ethnic Chinese business networks were dismantled in the south, women continued to operate illicit rural-urban and urban-rural trading and marketing networks, maintaining such activities both covertly and by bribing state regulators. This informal female-operated distribution system denied the state control of the resources it sought to channel into its centralist vision of the reunification project. In the mid 1980s the Doi moi reforms were announced with much fanfare. However, to a significant extent they merely legitimated the pre-existing arrangements of the informal economy. ${ }^{28}$

Goddesses such as the Lady of the Realm have long accompanied women as spiritual patrons in their trading and other endeavors and this remained true in the post war period, when women continued trading, albeit illegally. Yet some important shifts occurred as well. As more and more members of the ethnic Kinh majority moved into trading activities formerly monopolised by the ethnic Chinese, many were drawn to spirits such as the Lady of the Realm, who were associated with that entrepreneurial community's successes. As women's profile in the region's postwar trading economy grew the goddess herself assumed enlarged significance, mirroring women's own expanded achievements. The goddess acquired her reputation as especially responsive for overseeing difficult trading ventures at a time when such activity was proscribed and the risks of failure were especially high. Through the 1990s as petty trade became increasingly ubiquitous her fame spread among the influx of new recruits, urban and rural, to the commercial sector. Today, largely as a result of this history, the goddess is viewed as a business gatekeeper; one must seek her permission (xin phep) if one wants to engage in trade. The rise of this goddess to such stature is entwined in the history of women's informal resistance to economic centralisation. As such, she deserves some credit as an instigator of the liberal reforms, as do female traders who, in their transactions with her, raised her profile and popularised her qualities as a patron of business.

Today considerable prestige attaches to the goddess in attracting offerings from the most successful entrepreneurs in the region, the business class of its wealthiest urban areas such as Ho Chi Minh City, many of whom are women. In the village where the Lady of the Realm's shrine is found, one periodically sees large entourages of people from the city dressed in fine clothes descend from minibuses and cars and buses. They file in through the shrine's side entrance, holding aloft trays laden with entire roast pigs, piles of fruit, flowers, items of clothing and gold plaques. A leader parts the crowds and the procession approaches one of the rows of altars set up to handle the large volume of offerings. The ritual offerings are made with dramatic flourish, sometimes with the aid of a medium. The gold plaques and expensively embroidered robes and headpieces that they offer are on permanent display in dozens of cabinets that fill a three-storied hall beside the shrine. They are objects of wonderment and speculation and most visitors to the shrine spend some time viewing them. It is commonly observed that the largest offerings have come from urban business people from Ho Chi Minh City. This has led to a perception of the goddess as a patron of urban prosperity, and stories abound of her 
sponsorship of such ventures as real estate deals, moneylending, and house or vehicle rentals. These are routes to prosperity that many rural residents hope to emulate by migrating to the city. Among the many compacts nurtured in the precincts of the goddess's shrine include entreaties placed with her for sponsoring migration to Ho Chi Minh City and beyond. ${ }^{29}$ To many migrants now working in the commercial sector of the nation's largest city, their understanding of the goddess as an underwriter of urban fortunes is a view that was formed prior to, and is not simply a consequence of, their relocation to the city.

\section{SOCIALLY DIFFERENTIATING 'THE MARKET'}

Modernist critics of goddess worship with whom I have spoken are well aware that the people who work in the markets and commercial service sector of the city number among the goddess's most ardent followers. This would appear to be acknowledgement that the people who propitiate the goddess do indeed participate in the city's market economy and are engaged in its global integration through their involvement in trade, transport and small business. However, when confronted by evidence of the proximity and modernity of goddess worship such critics have continued to dispute the representativeness of these practices to the processes of modernisation and globalisation by pointing to their ethnic, gendered, and occupational specificity.

One of these approaches is to regard goddesses such as the Lady of the Realm as evidence of the historical influence on the ethnic majority population of matriarchal cultures such as the Cham. Such cultural borrowings may be of interest to anthropologists, but can scarcely have anything of relevance to offer those who consider themselves in the avantgarde of the transition to a globalised market-based society. Goddess beliefs are also widely seen as a cultural model introduced by the ethnic Chinese, who, notwithstanding their acknowledged business prowess, are often faulted by Vietnamese intellectuals as characteristically predisposed to 'superstition'. Alternatively, some argue that goddess beliefs find a hold among those lacking a solid education, whose ignorance leads them mistakenly to believe that spiritual forces guide their destiny. People such as market vendors and migrant workers in the commercial service sector, who lack equitable access to the centralized educational system, are likely to be influenced by such beliefs. Either way the propitiation of goddesses fails the culture test, either as influenced by non-Vietnamese culture or as indicating lack of exposure to a modern scientific cultural outlook. ${ }^{30}$

Another approach is to associate the practice of spirit worship with particular generational and gender identities. Often described as a pursuit of 'old women' ( $b a$ gia) at the end of their days, stereotypes of religious practice as backward looking, otherworldly, escapist or compensatory, are strongly gendered. Religious practice is often seen as a female predilection, stemming from a natural gender difference. Articles from the 1930s Saigonese magazine 'Modern Woman' wrote pejoratively of religious superstition as a problem that was widespread among women. ${ }^{31}$ In this vein, urban male acquaintances told me that women are prone to believe in others, or in external forces, rather than themselves. This opens them up for exploitation by religious charlatans. Men's lack of inclination for matters religious, by contrast, indicates their more self-reliant $(t u l u c)$ nature. Such self-reli- 
ance is commonly associated with modernity in Vietnam. For example, in the early twentieth century the 'self-strengthening' movement among the nationalist literati was an important vehicle for the introduction of ideas that it was thought would aid the modernizing of society. ${ }^{32}$ Science and the 'new learning' encouraged people to believe in themselves rather than in the power of obscure forces. Jamieson notes that, compared with the population as a whole, under the heavily urbanized Republic of Vietnam young, educated males had a more lineal view of time, a greater sense of personal efficacy vis-àvis nature and society, were more individualistic and more critical of traditional ways. ${ }^{33}$ Presented as such, 'progress' is a movement towards inclinations that are often gendered male in the Vietnamese cultural context.

Urban modernist intellectuals also approach the issue of goddess worship in terms of a stratified notion of the market economy. Tien imagined the urban project of 'modernisation' and international 'opening' to be typified by educated, foreign-language-speaking white-collar professionals such as himself. People who worked for a company (cong ty) in corporate planning, personnel management or market research were in the 'modern' domain. In such a realm the 'market' thi truong is something to be managed, that is to say mediated by 'rational' and 'scientific' principles. Pertaining to the world of corporate giants with foreign names and consumerist brands with global reach, this sector is located in the city 'centre' (trung tam) and new foreign investment enclaves. It is housed in new-style, high-rise, air-conditioned, steel and glass buildings and has its own language and dress codes. By contrast, those working in the unglamorous covered concrete marketplaces and outdoor sidewalk stalls of the city and elsewhere, he linked to 'superceded' (loi thoi) or at best 'transitory' (tam thoi) forms of economic activity. Tien considered activities in his own local market as unplanned and provisional, and marked by casual speech, dress codes and the proliferation of 'unscientific' forms of thinking and superstitious practices.

This distinction is also gendered, the former space predominantly male, the latter almost uniquely female. Such distinctions are encoded in different names given for the types of market, the term thi truong generally refers to the abstract idea of a modern market, where Tien imagined himself to work, while the term cho is used for the concrete, faceto-face, female dominated points of exchange that are ubiquitous features of the social landscape in urban and rural Vietnam. The category of 'private enterprises' (kinh doanh tu nhan), whose emergence is an anxiously attended index of the progress of the liberal reforms, does not generally include women's work in markets, described as 'petty trade' (buon ban nho), or as belonging to the 'informal sector' ${ }^{34}$ While Tien drew up advertising, marketing and distribution plans for spreading new consumer products through the Mekong delta countryside, he rarely himself set foot in his local market to buy such products for his own domestic consumption. This was done by his female relatives, his mother, wife and niece. Such a gendered division of labor is quite common in intellectual families in urban Vietnam, even as male intellectuals increasingly sell their expertise on the 'knowledge market'.

The distinction Tien maintained between his own work as a corporate professional and that done by marketers, creditors and traders in his local neighborhood market could be seen to reveal traces 
of a Confucian preference for scholarly and administrative occupations over those based in commerce, or of a traditional status hierarchy (si, cong, nong, thuong) that ranked the scholarly elite over peasants, workers and traders along mental/material lines. ${ }^{35}$ As such, the emergence of new professional identities and rationalities in Vietnam's urban centres has not only breathed new meaning into rural/urban, generational and gender distinctions but has given fresh meaning to older occupationally-based status distinctions. These distinctions confirm Hefner's observation that the globalisation of the market economy has not inevitably led to the effacement of locally-salient valences of culture or status. Instead, marketing, a rather longstanding practice within Vietnam, has accrued status through being amenable to 'reason' and gendered male attitudes, while stereotypically 'global' forms such as corporations acquire particular cultural and status meanings as they are divergently localised throughout the world.

However, the distinctions by which many Vietnamese urban professionals contemplate the market are not to be understood solely as time-bound cultural evaluations or traditionalist status reflexes. Rather they are practical strategies by which present-day actors attempt to secure their livelihoods in the complex and unstable economic environment of reform era Vietnam. During a decade and a half of educational and practical exposure to new ways of making a living, members of Vietnam's educated urban class have struggled to conform to new standards of professionalism and expertise and to carve out a position for themselves as employees working within new corporate forms. However, the premises upon which they engage the market are challenged by alternative avenues for personal advancement that characterise the society in which they live. Corruption, nepotism, access to overseas remittances and unregulated migration have fuelled the recent rise of much of Ho Chi Minh City's urban middle class, avenues to advancement that many educated professionals regard as provisory, unsustainable or illicit short-cuts to prosperity. Goddess worship is frequently linked by white collar professionals to illegitimate forms of livelihood, the perception being that reliance on protection from the spirit world is all too commonly the last resort of desperadoes and scoundrels. Their disparagement of those who seek refuge in spiritual protectors is tied to their critique of the improper involvement of officials in economic life and the proliferation of nefarious business ethics, which threaten to erode the competitiveness of the sector that employs them. Given that the Vietnamese government devotes as much attention to upholding the validity of goddess worship as it does to promoting Vietnam as a prime site for foreign investment, the critique of goddess worship issued by urban professionals is not necessary an ideologically dominant viewpoint but one enunciated from a standpoint of threatened vulnerability.

\section{CONCLUSION}

The Lady of the Realm occupies a prominent position among the figures responsible for the immense economic changes underway in the cities and market places of southern Vietnam. A spirit who symbolises and makes intelligible contemporary economic processes, she also embodies a form of historical consciousness, a condensation of what is popularly seen to have worked in the past. To those who propitiate her, the goddess is centrally implicated as a causative agent and 
contractual partner in their economic relationships. Very much an icon embodying for a significant sector of the urban population their historical experience of the market she is a symbol through whom people navigate the uncertainties of their commercial livelihoods and a reliable partner with whom they transact to achieve their goals.

Conversely, to the government and to many Vietnam's state-employed ethnologists and folklorists, goddesses such as the Lady of the Realm have been construed as reflecting the essence of 'national identity' (ban sac dan toc), an elusive property to be conserved and promoted, in order to provide Vietnamese citizens a cultural anchor in an era of rapid change and a bulwark against the worst ravages of globalisation. ${ }^{36}$ While stressing the durability of goddess beliefs and their exemplification of the deep roots of the Vietnamese soul, this appeal to goddesses as representative of the spiritual sources of Vietnamese identity can also be situated in the present. On the one hand the official endorsement of goddess worship as a venerable Vietnamese tradition is linked to government attempts to cultivate new subjectivities such as the 'family-based economy' compatible with its decentralised post-collectivist economic vision. ${ }^{37}$ On the other hand, the celebration of mother goddesses can be seen as a reactive interpretive project advanced by urban intellectuals to maintain status and cultural relevance during an era of unprecedented socio-cultural change. $^{38}$

Urban modernists' attitudes towards goddess worship similarly afford such a goddess an iconic status, even if to them she stands for a way of life that they evaluate negatively and wish to see abolished. To these iconoclasts, the Lady of the Realm is the focus of practices that they consider spatially removed, temporally outmoded, and of dubious social value. By mobilising distinctions of space, time and social value, their critical assessment of goddess worship exemplifies an alternative process of identity construction. Vietnam's iconoclastic modernists assert spatial, temporal and cultural boundaries between themselves and those who practice goddess worship, which circumscribe a position for themselves as the authentic representatives of Vietnamese urbanity, modernity and globalism. Intolerant as their critiques may seem, rather than dismiss such views as modernist fanaticism or, alternatively, as evidence of an enduring traditionalist patriarchy or of elitist disparagement of heterodoxy, we can see in this critique, like the practice of goddess worship itself, a form of action in the present that aims at securing a viable existence for a significant fraction of the urban community enmeshed as they are in a complex and volatile social context.

\section{ENDNOTES}

1 Philip Taylor, Goddess on the Rise: Pilgrimage and Popular Religion in Vietnam (Honolulu: University of Hawaii Press), 2004.

2 Pseudonyms are used for all people whose comments are cited in this article.

3 Ho Tai, Hue Tam, Millenarianism and Peasant Politics in Vietnam (Cambridge Mass: Harvard University Press, 1983). Son Nam, Ca Tinh cua Mien Nam (Ho Chi Minh City: Van Hoa), 1992.

4 Tran Van Giau, Su Phat Trien cua Tu Tuong o Viet Nam Tu the ky XIX den Cach Mang Thang Tam (The development of thought in Vietnam from 
the Nineteenth century to the August

Revolution), Vol. 1, (Hanoi: NXB

Chinh Tri Quoc Gia), 1996, 508.

5 Philip Taylor, 'Apocalypse Now? Hoa Hao Buddhism Emerging From the Shadows of War', The Australian Journal of Anthropology. Vol. 12, No. 3, 2001, 339-54.

6 Do Thien, Vietnamese Supernaturalism: Views from the Southern Region (London: RoutledgeCurzon), 2003. Phillip Taylor, 'Redressing Disadvantage or Rearranging Inequality? Development Interventions and Local Responses in the Mekong Delta', in Philip Taylor (ed.) Social Inequality in Vietnam and the Challenges to Reform (Singapore: Institute of Southeast Asian Studies), 2004, 259.

7 Thach Phuong 'May dac diem cua sinh hoat le hoi co truyen cua nguoi Viet o Nam bo', Van Hoa Dan Gian 2, Vol. 42, 1993, 21.

8 Doan Lam, 'A brief account of the cult of female deities in Vietnam' Vietnamese Studies No. 131, 1999, 8.

9 Nguyen Phuong Thao, Van Hoa Dan Gian Nam Bo (The Folk Culture of the Southern Vietnamese) (Hanoi: Education Publishing House), 1997.

10 Thach Phuong et al., Van Hoa Dan Gian Nam Bo (The Folk Culture of Southern Vietnam) (Ha Noi: Social Sciences), 1992, 89.

11 Ibid., 77.

12 Arjun Appadurai, Modernity at Large: Cultural Dimensions of Globalization (Minneapolis: University of Minnesota Press), 1996, 180.

13 Thach Phuong et al., Van Hoa Dan Gian Nam Bo, 1992.

14 For example, early in the 20th century, modernist intellectuals, endorsing a Social Darwinist evolutionist vision, proposed that the European method of honoring past figures for their historical contribution was to be preferred to the Vietnamese practice of making requests to the spirits of dead. See Phan Ke Binh, Vietnam Phong Tuc, annotated translation by Nicole Louis Henard, (Paris: Ecole Française d'Extreme-Orient), 1972, 1913-14.

15 Shaun Kingsley Malarney, Culture, Ritual and Revolution in Vietnam (London: RoutledgeCurzon), 2002.

16 Taylor, Goddess on the rise, 40.

17 Giebel 2001, 86; Shaun Kingsley Malarney 'The Fatherland Remembers Your Sacrifice: Commemorating War Dead in North Vietnam,' in Hue Tam Ho Tai, ed. The Country of Memory: Remaking the Past in Late Socialist Vietnam (Berkeley: University of California Press), 2001, 47. Taylor, Goddess on the Rise, 41, 214.

18 Phillip Taylor, 'The Goddess, the Ethnologist, the Folklorist and the Cadre: Situating Exegesis of Vietnam's Folk Religion in Time and Place', The Australian Journal of Anthropology, Vol. 14, No. 3, 2003, 383-401.

19 See also Le Thi, Employment and Life of Vietnamese Women during Economic Transition (Hanoi: The Gioi), 2001.

20 James Holston, 'Alternative Modernities: Statecraft and Religious Imagination in the Valley of the Dawn' American Ethnologist, Vol. 26 No. 3, 1999, 605-31.

21 Taylor, Goddess on the Rise, 124.

22 Ngo Duc Thinh (ed), Dao Mau o Viet Nam (The Mother Goddess Religion in Vietnam), (Nha Xuat Ban Thong Tin), 1996.

23 This goddess, enshrined in Bac Ninh province, obtained something of the notoriety among Hanoians that the Lady of the Realm achieved in Ho Chi Minh City and surrounding provinces at the same time. In the 1990s Ba Chua Kho was primarily associated with the borrowing of money, in contrast with the 
Chau Doc goddess, for whom financial assistance was but one element in a multiplicity of functions. Khanh Duyen, Tin Nguong Ba Chua Kho (The Lady of the Storehouse belief). (Ha Bac: So Van Hoa Thong Tin va The Thao), 1994.

24 Stevan Harrell, 'The Concept of Fate in Chinese Folk Ideology.' Modern China, No. 13, 1987, 90-109.

25 Hill Gates, China's Motor: A Thousand Years of Petty Capitalism (Ithaca: Cornell University Press), 1996, 168.

26 Peter Jackson, 'The Enchanting Spirit of Thai Capitalism: The Cult of Luang Phor Khoon and the Postmodernisation of Thai Buddhism', Southeast Asia Research, Vol. 7, No. 1, 1999, 5-60.

27 William Duiker, Vietnam Since the Fall of Saigon (updated edition) (Athens, Ohio: Ohio University Centre for International Studies), 1989. Philip Taylor, Fragments of the Present: Searching for Modernity in Vietnam's South (Honolulu: University of Hawaii Press), 2001.

28 These once illicit trading activities, although they preceded by centuries and have continued in tandem with the recent emergence of state-sanctioned private enterprises and foreign-owned companies, are commonly excluded in economists' historical characterisations of a nation 'in transition' from a centrally planned to a market economy (see for instance Adam Fforde, and Stefan de Vylder, From Plan to Market: The Economic Transition in Vietnam (Boulder Col.: Westview), 1995.

29 For an account of her reputed sponsorship of overseas migration see Taylor, Goddess on the Rise, 107.

30 For a more extended discussion of these viewpoints, see Phillip Taylor, 'The Ethnicity of Efficacy: Vietnamese Goddess Worship and the Encoding of Popular Histories.' Asian Ethnicity, Vol. 3, No. 1, 2002, 94.
31 Bui Thi Hoa, 'Phu nu voi cuoc van dong ton giao o Nam ky.' Phu Nu Tan Van, 28 November 1933, 225) 13-14. Bui Thi Hoa 1933, 13; Phu Nu Tan Van 1930, 5. Cartoons in the journal Culture and Arts Van Hoa Nghe Thuat in the early 1980s highlighted the stupidity of those who heeded the advice of fortune-tellers and let their lives go to wrack and ruin. Nearly always their customers were portrayed as older women in rural garb.

32 Neil Jamieson, Understanding Vietnam (Berkeley: University of California Press), 1993, 57.

33 Jamieson, Understanding Vietnam, 304. By contrast under the Democratic Republic of Vietnam in northern Vietnam, where similar goals of independence and social progress were to be achieved through collective effort, the qualities of selflessness and self-sacrifice for the collectivity were described as the key to being an authentic revolutionary, Malarney 'The Fatherland Remembers Your Sacrifice: Commemorating War Dead in North Vietnam,' in Hue Tam Ho Tai, ed. The Country of Memory: Remaking the Past in Late Socialist Vietnam, 52.

34 A 1991 survey showed that $78 \%$ of the owners of Vietnam's 'small to mediumsized private businesses' were men. Businesses in this category are defined by generally having more capital than the informal sector. They operate out of fixed places of production, are registered by the state, pay fixed taxes and usually require business management skills. According to a 2001 study, women account for $70 \%$ of the workers in the informal sector, which contributes $53.8 \%$ of the nation's GDP. See Le Thi, Employment and Life of Vietnamese Women During Economic Transition, 87, 77.

35 Luong Van Hy, ‘Engendered Entrepreneurship: Ideologies and political-economic transformation in a northern Vietnamese center of Ceramics production.' in Robert Hefner, ed. Market Cultures: Society and 
Morality in the New Asian Capitalisms (St Leonards: Allen and Unwin), 1998.

36 Taylor, 'The Goddess, the Ethnologist, the Folklorist and the Cadre: Situating Exegesis of Vietnam's Folk Religion in Time and Place', The Australian Journal of Anthropology, 390.

37 Jayne Werner, 'Gender, Household, and State: Renovation (doi moi) as Social Process in Viet Nam', in Jayne Werner and Daniele Belanger (ed.) Gender, Household, State: Doi moi in Viet Nam (Ithaca: Cornell Southeast Asia Program Publications), 2002, 29-48.

38 Taylor, 'The Goddess, the Ethnologist, the Folklorist and the Cadre', 395. 